\title{
Chapter 22 \\ Developing the Human, Material, and Structural Aspects of Infrastructure for Collaborative Curriculum Design: Lessons Learned
}

\author{
Susan McKenney
}

\section{Introduction}

During collaborative curriculum design (CCD), two objectives are typically pursued: curriculum innovation and teacher learning. In CCD, teams of educators typically work together to create curricular resources that can be used in everyday classroom settings. Sometimes teams create tools to be used only by themselves, but often they create materials for use by (themselves and) others. Generally, the curricula developed through CCD embody reform aspirations that are intended to enrich learner experiences or outcomes. Engaging in this process requires teachers to reflect on their own practice, challenge assumptions, share expertise, and negotiate meaning with regard to how to meet the needs of learners (Kali, McKenney, \& Sagy, 2015). As such, these processes form robust and viable sources of teacher professional development.

The interdependence between curriculum design and teacher learning has been well clarified in the introductory chapter of this book (Voogt, Pieters, \& Pareja Roblin, this volume), as well as for decades in the literature (e.g., Ben-Peretz, 1990; Stenhouse, 1980). Additionally, there is little dispute that pursuing the twin goals of curriculum innovation and teacher learning can be synergistic, especially when undertaken through the workings of CCD. The increasing recognition of these synergies has been demonstrated through multiple individual studies (e.g., Boschman, McKenney, \& Voogt, 2014; Cviko, McKenney, \& Voogt, 2014; Koehler \& Mishra, 2005) and a special issue of Instructional Science on teachers as designers of technology-enhanced learning (volume 43, 2015), as well as the chapters throughout this book. Alongside recognition of these synergies, research has also

\footnotetext{
S. McKenney $(\square)$

Faculty of Behavioral, Management and Social Sciences, University of Twente,

Enschede, The Netherlands

e-mail: susan.mckenney@utwente.nl
} 
demonstrated that high quality support is crucial for success (Binkhorst, Poortman, McKenney, \& van Joolingen, 2018; Kali \& Ronen-Fuhrmann, 2011).

The fact that curriculum innovation and teacher learning can be mutually beneficial does not mean that each of these processes requires the same support. In fact, each of these processes is complex and notoriously challenging. So, despite their synergies and natural interdependencies, combining the goal of curriculum innovation with the goal of teacher learning is extremely ambitious. Thus, to support CCD work well, it seems prudent to explore whether and how the support needed for curriculum innovation aligns with that needed for teacher learning, and vice versa. Additionally, it would be useful to identify any potential trade-offs or tensions between the respective forms of support required to achieve curriculum innovation and teacher learning. Toward this aim, the following section presents a lens through which to examine the supportive contexts of CCD.

\section{Infrastructure for Collaborative Curriculum Design}

\section{CCD Is Situated}

CCD does not take place in a vacuum, but within the dynamic and complex reality of educational settings. This means that the environments for CCD have crucial influence on CCD processes and on whether and how CCD processes yield the desired outcomes. Along with challenges, this situativity also holds opportunities for CCD. For example, curriculum innovation that is conceived in light of teacher daily practice stands a better chance of being implemented, because it takes into consideration the status quo, as well as the barriers and enablers present, in ways that help target incremental innovation toward what teachers and schools can implement with sustainable amounts of guidance or collaboration (McKenney, 2013). Similarly, research on teacher professional development has long stressed the need for teacher learning opportunities to be situated not outside of, but rather within the demands of daily practice (Van Veen, Zwart, Meirink, \& Verloop, 2010).

While many contextual factors play a role in the work of teachers, three wield particularly powerful influence on how they think, feel and act, both inside and outside of the classroom. These are the: human, material, and structural aspects of context. While these aspects play a crucial role in the daily experience of teachers, it is important to note that they are not always experienced as positive. For example, human expertise may be unwelcome when foisted upon teachers who do not recognize a need for it; materials that are poorly aligned with the curriculum may create extra burdens for teachers; or inconsistent policies may force teachers into conflicting roles. On the other hand, many other aspects are productive, such as: high quality coaches whose expertise is welcome; materials that increase teacher effectiveness or efficiency; or policies that enable teachers to access the expertise they need when they need it. The human, material, and structural aspects of context that make productive contributions to the work of teachers (and in this case, specifically, their $\mathrm{CCD})$, are referred to here as infrastructure. 


\section{Infrastructure}

Human aspects of infrastructure that influence the work of teachers include interactions with colleagues and experts, but especially with learners. Implicitly and explicitly, learners regularly provide teachers with knowledge about the consequences of their actions, which plays a crucial role in their professional development (Clarke \& Hollingsworth, 2002). Research in the learning sciences has emphasized the role that others play in the development of an individual's knowledge (Resnick, Levine, \& Teasley, 1991), and this definitely includes the learning of teachers (Borko, 2004). As is typical for workplace learning, teachers learn from the discourse and habits of communities that share the goal of fostering learner understanding and development (Brown \& Duguid, 1991; Cobb, 1994; Hord, 2009; Lave \& Wenger, 1991; Van Veen et al., 2010). Conversation, and to a lesser extent, writing are the most important activities through which members of teacher communities engage with one another (Avalos, 2011; Cochran-Smith \& Lytle, 2001). Conversation offers teachers essential opportunities to share knowledge, discuss what they want to learn, and become exposed to new concepts and strategies that meet the needs of their own contexts (Darling-Hammond \& McLaughlin, 1995). At the same time, research has also shown that rich opportunities to learn through teacher talk are more commonly the exception rather than the rule. This is the case with general teacher work groups (Horn, Garner, Kane, \& Brasel, 2016) as well as with teacher design teams (Boschman, McKenney, Pieters, \& Voogt, 2016; Boschman, McKenney, \& Voogt, 2015). In addition, given that high quality conversation depends on the skills required to identify and frame problems (and given that these skills are characteristic of particularly talented professionals), it is the competent teacher who mostly stands to gain from learning through conversations with colleagues (Horn \& Kane, 2015). These insights point to the crucial roles to be played by leadership (Binkhorst et al., 2018), new expertise (Hord, 2009; Van Veen et al., 2010), and a culture that stimulates exploration of arguments, plausible explanations, and new approaches (Ball \& Cohen, 1999).

Material aspects of infrastructure that shape teacher work include digital and analogue resources designed for individual or group use, inside or outside of the learning environment. Important tools for teachers can include those which are intended for use by the teachers themselves (such as teacher guides or computerbased planning applications) or by their learners (such as simulations or worksheets) (Putnam \& Borko, 2000). There is little doubt that lesson materials offer crucial support to all teachers, and especially to beginning teachers (Grossman \& Thompson, 2008). They can serve as vehicles for instructional improvement (Ball \& Cohen, 1996), especially when they attend not only to the needs of the learners, but also to the needs of teachers (Pareja Roblin, Schunn, \& McKenney, 2018). The characteristics of educative materials - resources that support the learning of both students and of teachers - are well described in the literature (Davis \& Krajcik, 2005; Drake, Land, \& Tyminski, 2014; Remillard, 2000; Remillard, HerbelEisenmann, \& Lloyd, 2011; Van den Akker, 1998). Alongside other resources, edu- 
cative materials can support ambitious teaching. Further, 'priming' tools help (especially beginning) teachers to unravel concepts and thus to gain insight into how learners can build on prior knowledge derived from everyday experiences or previous lessons (Windschitl, Thompson, Braaten, \& Stroupe, 2012).

Structural aspects of infrastructure include policies, norms, and routines that are ensconced in the organizational, local, or national system. For example, Handalzalts, Nieveen, and Van den Akker (this volume) alluded to structural aspects when drawing on a framework (Hargreaves, 2003) for understanding cultures and performance agreements. Policy is perhaps the most powerful structural aspect that can influence the work of teachers. Policy can support productive interactions, by creating the space and time for learning (Coburn \& Russell, 2008a; Darling-Hammond \& McLaughlin, 1995; Hord, 2009); by stressing that teacher talk should focus on learners (Coburn \& Russell, 2008b); by consistently emphasizing that teachers are, individually and collectively, responsible for learner performance; and by ensuring that teacher evaluations are conducted in ways that align with these values (Little, 1999; Van Veen et al., 2010). Policy can enable sustainable change by limiting the number of new initiatives prioritized simultaneously (Coburn \& Russell, 2008a); by ensuring the kind of long-term commitment to change that is necessary for innovations to take root in the organizational routines and practice of those involved (Garet, Porter, Desimone, Birman, \& Yoon, 2001; Penuel, Fishman, Yamaguchi, \& Gallagher, 2007; Van Veen et al., 2010); and by supporting a culture that embraces a shared appreciation of improvement science (Dolle, Gomez, Russell, \& Bryk, 2013). Finally, through conscious prioritization (e.g., financially), school, local, and national policies can support the initiation and maintenance of productive collaborations (Linn, Gerard, Matuk, \& McElhaney, 2016) such as those between schools and researchers (Coburn, Penuel, \& Geil, 2013; Lewis, Perry, \& Murata, 2006), between individual teachers and content specialists in their school (Diamond \& Spillane, 2004; Lee, Penfield, \& Maerten-Rivera, 2009), or between schools and those who offer professional development opportunities to teachers (Gerard, Bowyer, \& Linn, 2010).

\section{Infrastructuring}

It is not only the characteristics of the human, material, and structural aspects of context that play a role in shaping the work of teachers. Often, the processes through which they come to fruition are equally powerful. For example, policies that were created with input from teachers are likely to be more accessible and therefore more understood by other teachers; also, having a voice in policy development can create ownership, which, alongside clarity, also influences how policies are enacted. While some processes can have negative effects on how the human, material, and 
structural aspects of context are perceived and enacted, this chapter focuses on those that are productive. Specifically, it focuses on the work of infrastructuring.

Introduced by Penuel $(2015,2019)$ infrastructuring is an approach to facilitating the development of both durable change and equity between multiple stakeholders in intervention research. It combines concepts of participatory design (Dantec \& DiSalvo, 2013; Star \& Ruhleder, 1996) with concepts from educational change research (Hopkins \& Spillane, 2015; Hopkins, Spillane, Jakopovic, \& Heaton, 2013), and is highly relevant to CCD. As Penuel (this volume) noted, "To say that a goal of co-design is to infrastructure is to assert that a goal must be to create innovations that fit seamlessly within their work context and support users in making a reliable working infrastructure of those innovations." With the goal of supporting the work of infrastructuring in CCD, the following analysis revisits empirical findings from this book related to (developing) the human, material, and structural aspects of infrastructure that were found critical for supporting CCD work.

\section{Key Insights from Previous Chapters}

The goal of this section is to harvest key insights on infrastructuring curriculum innovation and teacher learning through CCD from the cases described throughout this book. While the studies described in this book address both curriculum innovation and teacher learning, each tends to foreground one goal over the other. In most cases, this means that they acknowledge, and where possible leverage, the synergies between these two processes for the CCD project work. At the same time, the primary goal of individual studies, and the main focus of data collection and analysis, tends to center on variables related to either curricular innovation or teacher learning. This is common in CCD projects, which are typically granted financial or institutional support through (a derivative of) one of these two basic arguments: (1) "To achieve our goals for curriculum innovation, investment in teacher learning is necessary and collaborative design can support both" or (2) "To achieve our goals for teacher learning, collaborative design of a curriculum innovation is a practical and effective approach."

This section therefore begins by characterizing the CCD processes and outcomes related to curriculum innovation and teacher learning respectively, based on studies that explicitly researched (the relationship between) CCD processes and CCD outcomes. Then, empirical findings concerning the (development of) human, material, or structural aspects of infrastructure to support CCD are discussed. Each of these is also positioned in light of the synergistic but distinctly different goals of curriculum innovation and teacher learning. NB: In the following paragraphs, key insights are shown in italics. 


\section{CCD Processes and Outcomes}

\section{Related to Curriculum Innovation}

In terms of CCD processes, Handelzalts (this volume) found that the activities and experiences to be highly varied, even in similar reform settings. He also found that, in general, the process of design is collaborative but construction is individual. That is, the teams often showed a pattern in which conceptualization, consideration of options, and mapping of solutions are discussed together, while the actual construction of materials is an individual exercise. Agyei (this volume) concluded that design teams can provide a platform for interaction and interdependence among teachers, which can prompt them to share knowledge and ideas. Akomaning (this volume) found that CCD was viewed by the stakeholders as a bottom-up approach for developing instructor capacity while also improving learning opportunities for students. Huizinga, Nieveen, and Handelzalts (this volume) examined how teachers in CCD teams whose materials are ripe for dissemination attend to implementation by others who were not engaged in CCD. In their study, the CCD teachers were sensitive to the needs of others to understand and implement reform. That is, they anticipated the need to enhance their colleagues' ownership of the materials and initiated various activities to help develop this. These activities included collaborative preparation for classroom implementation, offering exemplary materials, and discussing video recordings of lessons.

In terms of (influencing) CCD outcomes, Handelzalts (this volume) showed that having a clear vision supports productivity. Specifically, teams with clearer common reform ambitions and positive dispositions toward the reform initiative were better able to jump into designing and rethinking their curriculum. Conversely, teams that started off with a vague reform mission needed (much time) to reach sufficient clarity about organizational conditions before starting to work on their plans. Further, teachers who began the process with little direction (which is often wellintended - to give teams freedom) experienced great difficulty; these groups focused on procedural elements, and regarded practicality as the main quality criterion for their products. In line with this finding, Handelzalts concluded that structure supports productivity. His data show that the more structure there is, the more actual construction gets done. Further, it does not seem to matter if the structure is introduced by others (e.g., a collaborator deciding it is time for a meeting), or if it emerges from the group (e.g., the team decides together how to proceed at the end of a meeting), as long as it is present. In their exploration of scientific and colloquial evidence on CCD, Westbroek, de Vries, Walraven, Handelzalts, and McKenney (this volume) found that CCD supported the alignment of curricular ideals with the perceived and sometimes also the attained curriculum. These outcomes, however, tended to vary along with the corpus of literature in which they were presented (scientific journals or professional journals). Namely, the professional literature showed effects relating to the alignment of the ideal curriculum going all the way to the attained curriculum, whereas the scientific literature focused on the effects of aligning the ideal and the perceived curriculum. Negative influences on CCD outcomes 
were also identified in this volume. Bakah, Nihuka and Gendole (this volume) found that CCD may conflict with an existing culture of collaboration, which can be a hindrance to a team's ability to function. They also found that CCD may conflict with existing schedules and responsibilities. They highlighted the importance of understanding how structural conditions give or take away time for the development of CCD work (e.g., pressuring teachers to obtain higher qualifications outside of the university leaves them very little time for innovation). While indirect measures of curriculum quality were taken into consideration in several studies (e.g., how new users perceive the products of $\mathrm{CCD}$ ), none of the studies in this volume reported on direct measures of the quality of the curricula developed.

\section{Related to Teacher Learning}

Nihuka (this volume) found that the process of CCD was characterized by exchange and validation of expertise. That is, CCD provided an opportunity for instructors to discuss the challenges of traditional practice, as well as the rationale for and potential of e-learning technologies. This resulted from instructors sharing expertise, acknowledging each other's good ideas, and collaborating with regard to course organization and delivery. In addition, when Huizinga, Nieveen, and Handelzalts (this volume) studied the implementation of CCD products, their classroom observations revealed highly varied classroom implementation across teachers both within and between different teams. They found that CCD participants did possess design expertise, but had limited (analysis or) evaluation knowledge and skills. That is, the teams rarely conducted evaluation activities on their own and if they did, these were unstructured and very closely related to their regular-day classroom tasks. They also found that the classroom implementation and evaluation processes were affected by teachers' understanding of the reform, their pedagogy, and especially their role in the CCD work.

With regard to CCD outcomes, the instructors in Nihuka's study (this volume) improved their understanding and appreciation of the reform through CCD, and their resulting course design had a positive impact on both teacher practices and student outcomes. Similarly, several other studies showed that CCD is promising for professional development because it contributed to improved knowledge and skills (Alayyar \& Fisser, this volume; Bakah, this volume; Gendole \& Coenders, this volume), while also generating ownership of and commitment to the reform (Alayyar \& Fisser, this volume). Finally, as was the case with their investigation of scientific and professional literature on CCD for curriculum innovation, Westbroek, de Vries, Walraven, Handelzalts, and McKenney (this volume) found that the professional development outcomes reported in the literature varied by source type. Namely, they found that the professional literature portrayed CCD effects including experiencing relevance, teambuilding and (resulting from these) ownership. The scientific literature they reviewed also showed that teachers experienced relevance and appreciation for their active involvement, but that other specific learning yields were difficult to pinpoint. 


\section{Human Aspects of Infrastructure to Support CCD}

\section{For Curriculum Innovation}

Several studies yielded empirical findings related to the roles of participants in CCD. As noted previously, Westbroek, de Vries, Walraven, Handelzalts, and McKenney (this volume) identified differences based on the corpus of literature being examined (scientific or professional). In all cases, they concluded that (perceived) roles differ, by project and person, but they also found that teams described in the scientific corpus were primarily researcher-led, with teachers in the role of learners. Conversely, the professional corpus painted a picture in which teams were primarily teacher-led, with teachers serving as experts. In another study, team characteristics (and not just the clarity of the initial reform) influenced CCD team functioning (Handalzalts, this volume). Similarly, in their examination of development work informed by research, Pareja Roblin and McKenney (this volume) identified a primary knowledge source informing innovation development: the expertise of the multidisciplinary team. Further, they found that university researchers took on the tasks of assessing quality, utility, feasibility or effectiveness; content specialists contributed to the design of the innovation as well as assisting researchers with data collection and advising teachers or students during implementation. The role of teachers was more reactive (giving viewpoints or feedback on the quality or effectiveness of prototypes), but that is not surprising as this study did not focus on codesign, per se.

Several studies pointed to the crucial role of leadership for supporting CCD. Albashiry (this volume) found that curricular leadership was required for sustained and systematic work. He also identified multiple forms of professional development that are required for curricular leaders, including training, coaching, exemplary materials, handouts, and templates. In addition, commitment from management was found to be crucial; for example, teacher enthusiasm was boosted when leaders encouraged the formation of new design teams (Bakah, Nihuka, \& Arkato Gendole, this volume). For CCD to succeed, there must be a leadership style attuned to team needs (Handelzalts, this volume). For example, when a flexible and emergent reform strategy is used with teams that have a vague reform ambition, a more proactive and involved role is required from management. Finally, for sustained development, it is important to enact distributed leadership and responsibility, alongside creating a culture of support (appreciating successes, being responsive, giving follow-up, asking for it and using feedback from learners and parents) (Handelzalts, Nieveen, \& Van den Akker, this volume).

A third dimension of the human aspects of infrastructure emerging from these studies relates to developing shared understanding and expectations. Two studies in particular stressed the importance of involving more participants than just teachers in CCD for curriculum development. In one case (Akomaning, this volume), key 
contributors were not only teachers, but also other stakeholders, including those from industry, industrial liaison officers, and students. Developing shared awareness was crucial, especially with these other stakeholders. Similarly, Gervedink Nijhuis (this volume) identified the need to involve local stakeholders as developers, experts, or instructors as well as to facilitate local stakeholders in dealing with transfer and problem-solving conditions that support implementation. Her data revealed the need to understand the expectancies and preferences of participants, in terms of tasks, responsibilities, communication strategies, time perceptions, and financial remuneration. They also suggested that the goals of CCD work are best served when participants are willing, open-minded, and culturally sensitive about appreciating differences. This may explain why a blend of systematic and relational approaches was found to be a major contributor to the internal and external consistency of the resulting curricula in one of the studies (Albashiry, this volume).

\section{For Teacher Learning}

For the goal of supporting teacher learning through CCD, data showed that experts facilitate sharing, and that this served team functioning. Kafyulilo and Fisser (this volume) reported improvements in teachers' self-reported and observed knowledge related to integrating technology into their science and mathematics teaching. Their findings indicated that this happened by sharing knowledge, skills, experiences, and challenges, and this sharing was due to the expert facilitation including substantive expertise in science and education technology. Similarly, Huizinga, Nieveen, and Handelzalts (this volume) portrayed the crucial role played by facilitators in supporting reflection and sharing of experiences. They identified three gaps in teachers' design expertise (curriculum design expertise, pedagogical content knowledge, curricular consistency expertise) and suggested that facilitators must be able to help teachers address these gaps. They stressed that facilitators themselves require a deep understanding of curriculum design, including the ability to identify which design approach is most fitting in a given situation. Further, their data indicated that facilitator support styles should be both proactive and reactive. The former helps ensure that all important steps are undertaken, and the latter comes more naturally to most CCD teams.

In addition to the role of facilitators, studies also pointed to the importance of project coordination and management support for CCD to support teacher learning. In their second chapter, Huizinga, Nieveen, and Handelzalts (this volume) showed why CCD team coordinators require basic planning and monitoring skills to manage and lead CCD teams well, and their role in helping foster ownership of CCD outcomes that are to be carried forward in an organization. For similar reasons, Agyei and Kafyulilo (this volume) also stressed the importance of management support. 


\section{Material Aspects of Infrastructure to Support CCD}

\section{For Curriculum Innovation}

In these studies, documents were the most common form of materials to productively support curriculum innovation though CCD. This included research literature as a knowledge source for informing innovation development (Pareja Roblin \& McKenney, this volume) as well as high quality guiding documents, such as those that helped streamline the implementation described by Akomaning (this volume). Exemplary curriculum materials were also mentioned as important sources of inspiration that promote better understanding of the reform (Akomaning, this volume), not only for their practical use, but also because discussion of concrete plans and products in which abstract ideas have been made tangible and accessible benefits participant understanding (Handelzalts (this volume).

\section{For Teacher Learning}

Documents were also the most frequently mentioned form of material support for teacher learning through CCD. Research showed that external support can be given through templates and tools that help teams evaluate and select source materials, for example, or conduct formative evaluation of the CCD products with students (Huizinga, Nieveen, \& Handelzalts, this volume). Kafyulilo and Fisser (this volume) attributed improvement of teacher expertise for integrating technology into their science and mathematics teaching to three forms of documents, namely: collaboration guidelines, exemplary lessons, and (online) learning material (e.g., literature).

Two studies collected data on the role of digital tools. In the study by Alayyar and Fisser (this volume), the blended support environment was deemed to be as effective as the human support environment for developing the competencies and attitudes required, but the blended environment additionally included the possibility of communication among team members, between different teams, and with the course instructor. Participants appreciated this flexibility of the online environment. Further, Agyei (this volume) found that readily available resources are more likely to influence teacher daily practice.

\section{Structural Aspects of Infrastructure to Support CCD}

\section{For Curriculum Innovation}

Bakah, Nihuka, and Arkato Gendole (this volume) stressed the need to incorporate CCD in the policy structure of the organizations. Their data showed that failure to do so creates vulnerability of the innovation at the departmental and institutional 
levels. They showed how policy, habits, and organizational messages can be shaped to support CCD. Similarly, Albashiry (this volume) found that curricular leadership for sustained and systematic work was helped by incorporating a decrease in workload for participants, providing incentives, and flexibility in scheduling training sessions and other activities. In his study, these policy-endorsed structures created a positive work environment, positive attitudes toward the undertaking, and alleviated temporal tensions (with commitments to other activities).

In addition, findings in these studies showed the need for carefully shaping participation. For example, Handelzalts, Nieveen, and Van den Akker (this volume) identified a need to provide structures for less formal interaction within and among teams. Their study found that CCD teams benefit from two kinds of activities to compensate for the typical lack of informal interaction: (1) presentation of team progress to give an overview of development, share insights, and discuss challenges; and (2) study days to obtain clarity about the focus of the reform, culminating in the creation or receiving of easily applicable products (such as a timeline for envisioning the work process, or a framework for describing the curricular resources they are designing). Additionally, their findings demonstrated why it is important to promote a focus on learners. That is, the norms, expectations and conditions may allow teams to think broadly at times, but clearly ensure that learners remain at the center of the reform. For cases in which the designed materials are used by non-designers, Pareja Roblin and McKenney (this volume) identified the need to (set up structures that) involve local organizations that can assist teachers and project leaders with implementation, before diffusion to other sites.

For several studies, planning for evolution, including the timelines to realize this, proved essential. First, the data from Albashiry (this volume) clarified why timelines need to be long-term and realistic. Namely, a relatively extended time spent on CCD work is necessary to yield, implement, and sustain innovation. This is benefited by piecemeal evolution, which helps teachers cope with the novelty and complexity over time. This is why Handelzalts, Nieveen, and Van den Akker (this volume) advocated that the timelines allow teams to think big, but start small (i.e., formulate schoolwide intentions, but work stepwise toward these ends), while taking the time to attend to the fact that one size does not fit all (use a common framework, but provide room for specific choices). As well as in these two studies, the need to accommodate gradual, iterative work was identified in a literature review of both scientific and professional sources (Westbroek, de Vries, Walraven, Handelzalts, $\&$ McKenney (this volume). In addition, Gervedink Nijhuis (this volume) stressed the need to plan for adjustments that are informed by essential iterations, which were helpful for: continuous (re-)analysis of cultural influences and stakeholder preferences, and evolutionary design, especially in the early stages, to attend to cultural influences on stakeholder perceptions and transfer experiences. This aligns well with the findings of Handelzalts, Nieveen, and Van den Akker (this volume), who found the need to structurally promote early experimentation. They noticed that teachers require help with envisioning their (potential) future practice, and observed that pilots for implementation of partial materials had a positive effect on teacher understanding of reform implications for their students. 
Finally, studies on curriculum innovation through CCD identified benefits associated with regular access to expertise in various forms. Handelzalts, Nieveen, and Van den Akker (this volume) found that teams benefited from having opportunities to engage with explicit information on the reform ambitions, and that this can come from external input as well as by undertaking site visits to schools implementing the desired kinds of reform. The literature review by Westbroek, de Vries, Walraven, Handelzalts, and McKenney (this volume) confirmed the importance of (structuring regular access to) external support. Their scientific corpus suggested that this was theory-driven and structural, whereas their professional corpus showed that this was most often concern-driven and incidental. Access to expertise in a packaged form was also identified as beneficial. Specifically, Agyei (this volume) observed that teams benefited from an orientation program that provided conceptual and theoretical information and linked this to practical applications, each of which was based on the research literature. Further, his finding that scaffolds for the desired types of teaching and learning experiences (embodying research-based expertise) made the most significant contribution to developing desired competencies explains why he argued for their structural integration.

\section{For Teacher Learning}

As with CCD for curriculum innovation, studies showed that the plans and structures that accommodated the strophic processes of experimentation-reflection were important for teacher learning. First, making the time for implementation of the redesigned curriculum materials in the classroom was a crucial factor that contributed to professional growth (Bakah (this volume). Second, in their study on teacher development of curriculum design expertise through implementation activities, Huizinga, Nieveen, and Handelzalts (this volume) found that the CCD teams required planned, explicit support for evaluation activities.

To support teacher learning both within and across teams, the establishment of organizational routines was found to be crucial. Handelzalts, Nieveen, and Van den Akker (this volume) identified a need to provide structures for collaboration in and among teams. Further Huizinga, Nieveen and Handelzalts (this volume) observed that the number of support meetings is important. Their data also clearly indicated that support meetings must take place throughout all phases of the design process (to help teachers understand the importance of analysis and evaluation activities, as well as design sub-steps).

Finally, Arkato Gendole and Coenders (this volume) pointed to a well-known but often under-estimated structural aspect of infrastructure, the reward system. Their data showed how the provision of external rewards such as financial incentives and certificates can play an important role in setting the stage for teacher engagement with CCD learning opportunities. Accordingly, the rewards must be aligned with career perspectives, for example, by boosting opportunities for promotion or endorsing the development of valued skills. 


\section{Reflections}

\section{Synthesis}

To support future CCD work, the previous section reviewed the processes and outcomes of CCD, and the human, material, and structural aspects of infrastructure that could support them. To understand synergies and explore potential tensions between the supports needed, the discussion was structured in light of the two main goals of CCD: curriculum innovation and teacher learning. Table 22.1 synthesizes the key insights described above. Bold text in the table indicates within-column similarities, such as human aspects of infrastructure that were found to be important for both curriculum innovation and teacher learning.

\section{Discussion}

The findings synthesized in Table 22.1 shed new light on details of supportive CCD infrastructure, and clarify which elements apply to CCD in general, and which ones are needed for CCD aiming primarily at curriculum innovation or at teacher learning. While Table 22.1 offers new elements and nuances, the key themes identified are largely consistent with findings from other studies on curriculum innovation and teacher learning. Here, attention is given to the themes within each aspect of infrastructure that were found to be similar for both goals.

Key themes related to the human aspects of infrastructure required in both cases were leadership, expert facilitation, and the presence of specific and varied expertise within the CCD team. The importance of leadership in CCD has been identified in other studies (Binkhorst, Poortman, \& Van Joolingen, 2017), along with the fact that providing adequate leadership is challenging (Becuwe, Tondeur, Pareja Roblin, Thys, \& Castelein, 2016). Further, commitment from leadership was shown to be essential, especially for ensuring that activities and resources are directed toward activity that would be productive for meeting CCD goals. The importance of unravelling how power and authority affect CCD was discussed by Penuel (this volume). Further, existing research is aligned with the finding that CCD requires expert facilitators (Boschman et al., 2016). The facilitator's task of combining both shared and vertical leadership styles has been described as challenging, even paradoxical (Binci, Cerruti, \& Braganza, 2016). Binkhorst et al. (2018) described a stepwise approach to supporting the combination of both vertical and shared leadership, though they acknowledged that this work remains a challenging balancing act. Finally, these studies are aligned with previous research which shows that, within the team (and across all roles) CCD requires specific and varied expertise. This includes knowledge of models and frameworks to guide design; participant experiences as well as reflections on and responses to the environment; and knowledge of what designers actually do, as well as how and why they do it (McKenney, Kali, 
Table 22.1 Findings on the processes and outcomes of $\mathrm{CCD}$, and the infrastructure to support them

\begin{tabular}{|c|c|c|c|c|}
\hline & \multirow{2}{*}{$\begin{array}{l}\text { CCD processes } \\
\text { and outcomes }\end{array}$} & \multicolumn{3}{|c|}{ Infrastructure to support CCD } \\
\hline & & Human & Material & Structural \\
\hline \multirow[t]{12}{*}{$\begin{array}{l}\text { Curriculum } \\
\text { innovation }\end{array}$} & Processes to expect & Anticipate roles & $\begin{array}{l}\text { Provide } \\
\text { documents }\end{array}$ & Policy \\
\hline & $\begin{array}{l}\text { Highly varied } \\
\text { (even in similar } \\
\text { reform settings) }\end{array}$ & $\begin{array}{l}\text { Understand that } \\
\text { (perceived) roles } \\
\text { differ by project and } \\
\text { by person }\end{array}$ & $\begin{array}{l}\text { Research } \\
\text { literature } \\
\text { (theoretical and } \\
\text { empirical) }\end{array}$ & Decrease workload \\
\hline & $\begin{array}{l}\text { Design is } \\
\text { collaborative but } \\
\text { construction is } \\
\text { individual }\end{array}$ & $\begin{array}{l}\text { Team characteristics } \\
\text { mediate team } \\
\text { functioning }\end{array}$ & $\begin{array}{l}\text { High quality } \\
\text { guiding } \\
\text { documents }\end{array}$ & Provide incentives \\
\hline & $\begin{array}{l}\text { Interaction and } \\
\text { interdependence }\end{array}$ & $\begin{array}{l}\text { Multidisciplinary } \\
\text { expertise in team is } \\
\text { beneficial }\end{array}$ & \multirow{9}{*}{$\begin{array}{l}\text { Exemplary } \\
\text { materials, lesson } \\
\text { plans, and } \\
\text { products } \\
\text { embodying the } \\
\text { abstract reform } \\
\text { ideas and } \\
\text { scaffolding desired } \\
\text { practices }\end{array}$} & $\begin{array}{l}\text { Schedule } \\
\text { meetings (requires } \\
\text { flexibility in the } \\
\text { organization) }\end{array}$ \\
\hline & $\begin{array}{l}\text { Viewed as } \\
\text { bottom-up }\end{array}$ & Ensure leadership & & $\begin{array}{l}\text { Shape } \\
\text { participation }\end{array}$ \\
\hline & $\begin{array}{l}\text { Includes } \\
\text { sensitization to } \\
\text { needs of others (to } \\
\text { understand and } \\
\text { implement reform) }\end{array}$ & $\begin{array}{l}\text { Curricular } \\
\text { leadership }\end{array}$ & & $\begin{array}{l}\text { Provide } \\
\text { structures for less } \\
\text { formal } \\
\text { interaction within } \\
\text { and among teams }\end{array}$ \\
\hline & Outcomes found & $\begin{array}{l}\text { Commitment from } \\
\text { management } \\
\text { crucial }\end{array}$ & & $\begin{array}{l}\text { Promote focus on } \\
\text { learners }\end{array}$ \\
\hline & $\begin{array}{l}\text { Clear vision } \\
\text { supports } \\
\text { productivity }\end{array}$ & $\begin{array}{l}\text { Leadership style } \\
\text { attuned to team } \\
\text { needs }\end{array}$ & & $\begin{array}{l}\text { Involve local } \\
\text { organizations } \\
\text { before diffusion }\end{array}$ \\
\hline & $\begin{array}{l}\text { Structure supports } \\
\text { productivity }\end{array}$ & $\begin{array}{l}\text { Culture of support, } \\
\text { responsibility and } \\
\text { distributed } \\
\text { leadership }\end{array}$ & & Plan for evolution \\
\hline & $\begin{array}{l}\text { Alignment of } \\
\text { ideals with } \\
\text { perceived and } \\
\text { (sometimes) } \\
\text { attained curriculum } \\
\end{array}$ & $\begin{array}{l}\text { Develop shared } \\
\text { understanding and } \\
\text { expectations }\end{array}$ & & $\begin{array}{l}\text { Use long-term and } \\
\text { realistic timelines }\end{array}$ \\
\hline & May conflict & $\begin{array}{l}\text { Involve stakeholders } \\
\text { and facilitate them }\end{array}$ & & $\begin{array}{l}\text { Accommodate } \\
\text { gradual, iterative } \\
\text { work }\end{array}$ \\
\hline & with existing & $\begin{array}{l}\text { Develop shared } \\
\text { awareness }\end{array}$ & & $\begin{array}{l}\text { Promote early } \\
\text { experimentation }\end{array}$ \\
\hline
\end{tabular}


Table 22.1 (continued)

\begin{tabular}{|c|c|c|c|c|}
\hline & \multirow{2}{*}{$\begin{array}{l}\text { CCD processes } \\
\text { and outcomes }\end{array}$} & \multicolumn{3}{|c|}{ Infrastructure to support CCD } \\
\hline & & Human & Material & Structural \\
\hline & collaboration & $\begin{array}{l}\text { Understand, expect, } \\
\text { and appreciate } \\
\text { individual and } \\
\text { cultural differences }\end{array}$ & & $\begin{array}{l}\text { Provide access to } \\
\text { expertise }\end{array}$ \\
\hline & $\begin{array}{l}\text { culture, schedules, } \\
\text { or responsibilities }\end{array}$ & $\begin{array}{l}\text { Blend systematic } \\
\text { and relational } \\
\text { approaches }\end{array}$ & & $\begin{array}{l}\text { Facilitate external } \\
\text { input (experts, site } \\
\text { visits) }\end{array}$ \\
\hline & & & & $\begin{array}{l}\text { Promote use of } \\
\text { data (from } \\
\text { analysis or } \\
\text { evaluation) }\end{array}$ \\
\hline & & & & $\begin{array}{l}\text { Promote use of } \\
\text { research literature }\end{array}$ \\
\hline $\begin{array}{l}\text { Teacher } \\
\text { learning }\end{array}$ & Processes to expect & $\begin{array}{l}\text { Prepare expert } \\
\text { facilitators to } \\
\text { support sharing }\end{array}$ & $\begin{array}{l}\text { Provide } \\
\text { documents }\end{array}$ & $\begin{array}{l}\text { Endorse } \\
\text { experimentation- } \\
\text { reflection }\end{array}$ \\
\hline & $\begin{array}{l}\text { Exchange and } \\
\text { validation of } \\
\text { expertise }\end{array}$ & $\begin{array}{l}\text { Of knowledge, } \\
\text { skills, experiences, } \\
\text { challenges }\end{array}$ & $\begin{array}{l}\text { Templates and } \\
\text { tools }\end{array}$ & $\begin{array}{l}\text { Implementation } \\
\text { of the (re-) } \\
\text { designed materials } \\
\text { was crucial for } \\
\text { their learning }\end{array}$ \\
\hline & $\begin{array}{l}\text { Highly varied } \\
\text { classroom } \\
\text { implementation } \\
\text { (even in similar } \\
\text { settings) }\end{array}$ & $\begin{array}{l}\text { Expert facilitation } \\
\text { needed to support } \\
\text { reflection (e.g., on } \\
\text { classroom } \\
\text { implementation) }\end{array}$ & $\begin{array}{l}\text { Exemplary lesson } \\
\text { materials }\end{array}$ & $\begin{array}{l}\text { Planned, explicit } \\
\text { support for } \\
\text { evaluation (and } \\
\text { use of its data) }\end{array}$ \\
\hline & $\begin{array}{l}\text { Design expertise } \\
\text { present, but limited } \\
\text { (analysis or) } \\
\text { evaluation } \\
\text { knowledge and } \\
\text { skills }\end{array}$ & $\begin{array}{l}\text { Substantive } \\
\text { expertise needed/ } \\
\text { shared in team }\end{array}$ & $\begin{array}{l}\text { Collaboration } \\
\text { guidelines }\end{array}$ & $\begin{array}{l}\text { Develop } \\
\text { organizational } \\
\text { routines }\end{array}$ \\
\hline & Outcomes found & $\begin{array}{l}\text { Design process } \\
\text { expertise needed by } \\
\text { facilitators }\end{array}$ & $\begin{array}{l}\text { Learning and } \\
\text { informative } \\
\text { literature }\end{array}$ & $\begin{array}{l}\text { Provide } \\
\text { structures for } \\
\text { collaboration } \\
\text { within and } \\
\text { among teams }\end{array}$ \\
\hline & $\begin{array}{l}\text { Improved } \\
\text { understanding and } \\
\text { appreciation of } \\
\text { reform }\end{array}$ & $\begin{array}{l}\text { Blend of proactive } \\
\text { and reactive } \\
\text { facilitator support }\end{array}$ & $\begin{array}{l}\text { Consider digital } \\
\text { tools }\end{array}$ & $\begin{array}{l}\text { Ensure sufficient } \\
\text { number of } \\
\text { support meetings }\end{array}$ \\
\hline
\end{tabular}


Table 22.1 (continued)

\begin{tabular}{l|l|l|l|l}
\hline \multirow{2}{*}{$\begin{array}{l}\text { CCD processes } \\
\text { and outcomes }\end{array}$} & \multicolumn{3}{|l|}{ Infrastructure to support CCD } \\
\cline { 2 - 4 } & $\begin{array}{l}\text { Increased } \\
\text { knowledge and } \\
\text { skills (e.g., CLT, } \\
\text { e-learning, } \\
\text { affordances and } \\
\text { constraints of } \\
\text { [technology-based] } \\
\text { resources, } \\
\text { engineering) }\end{array}$ & $\begin{array}{l}\text { Ensure project } \\
\text { coordination and } \\
\text { management } \\
\text { support }\end{array}$ & $\begin{array}{l}\text { Communication } \\
\text { tools }\end{array}$ & $\begin{array}{l}\text { Ensure that } \\
\text { meetings continue } \\
\text { throughout all } \\
\text { phases }\end{array}$ \\
\hline $\begin{array}{l}\text { Ownership, } \\
\text { commitment and } \\
\text { appreciation }\end{array}$ & $\begin{array}{l}\text { Planning and } \\
\text { monitoring skills } \\
\text { needed }\end{array}$ & $\begin{array}{l}\text { Readily available } \\
\text { resources are more } \\
\text { likely to influence } \\
\text { daily practice }\end{array}$ & $\begin{array}{l}\text { Review reward } \\
\text { system }\end{array}$ \\
\cline { 2 - 5 } & $\begin{array}{l}\text { Support from } \\
\text { management } \\
\text { crucial }\end{array}$ & External rewards \\
\hline
\end{tabular}

Bold indicates within-column similarities between curriculum development and teacher development

Markauskaite, \& Voogt, 2015), in addition to the knowledge, skills and attitudes teachers need to understand and meet the needs of their learners (McKenney, 2017).

The material aspects of infrastructure that are crucial for both curriculum innovation and teacher learning through CCD include exemplary materials, tools and literature. Well-crafted exemplary materials support teacher understanding of reform intentions, subject matter content, pedagogy, or classroom orchestration (Pareja Roblin, Schunn, Bernstein, \& McKenney, 2018). Tools supporting the work of teachers as designers can take multiple forms, including real-time or asynchronous communication aids, implicit or explicit procedural guidance, and customized or generic templates (McKenney, 2008). Given that scholars have often lamented practitioners' lack of interest in or use of literature, it seems promising that CDD teams craved it. But challenges of physical and intellectual accessibility of the literature persist. Further, to be effective, authors will need to attend to the distinct priorities that guide teacher perceptions and use of educational research and evidence-based practices (Neal, Mills, McAlindon, Neal, \& Lawlor, 2018).

Key supportive aspects of the CCD infrastructure were shown to include organizing time together, use of data, and iterative experimentation. The need to organize time for collaboration has been stressed in the literature repeatedly (e.g., in the review study by Van Veen et al., 2010). The issue has now become not whether time to work together is important, but rather, why does it seem so difficult for decision makers to understand? Data-informed decision making has long been good practice among designers, and has more recently been embraced by schools. Increasingly, resources have become available to guide educators toward making responsible use of data (e.g., Schildkamp, Lai, \& Earl, 2012). In a similar vein, while early, agile, and iterative experimentation has been a cornerstone of design work for decades, 
CCD teams have often struggled for structural accommodation of such work (e.g., due to unrealistic project timelines or naïve understanding of CCD processes). This seems surprising given that experimentation has been widely recognized as essential to both curriculum innovation (Tytler, Symington, \& Smith, 2011) and teacher learning (Clarke \& Hollingsworth, 2002).

While the general findings shown in Table 22.1 do align with previous research on (CCD for) curriculum innovation and teacher learning, it is useful to notice similarities and distinctions between findings from projects with curriculum innovation as a primary rationale or goal, as opposed to those with teacher learning with a primary rationale or goal. First, as discussed above, there are similarities in several aspects of the desired infrastructure for productively supporting both curriculum innovation and teacher learning through CCD. As such, those aspects (in bold) could be considered essential for any CCD endeavor. Second, there are clear differences between the two. Understanding the differences in support needs seems crucial for providing an adequate infrastructure for the specific goals of a particular CCD project. Third, there do not appear to be any obvious tensions between the processes and outcomes related to each goal. This is not a surprise given the stance taken throughout this volume - that curriculum innovation and teacher professional development are mutually beneficial. Still, given that synergies and tensions often co-exist, it seems useful to have reviewed empirical evidence on this point. Similarly, no tensions seem evident between the human, material, or structural aspects of infrastructure CCD for each goal. Finally, it is worth noting that there were very limited data on the processes of infrastructuring. This shows that, at least for these cases, infrastructuring was rarely the explicit focus of empirical inquiry.

Even though specific tensions between support needs for curriculum innovation and for teacher learning do not appear to be present, it is clear that the overall support needs are extensive. As a result, it seems likely that most CCD projects would struggle to adequately meet the support needs for achieving either goal of curriculum innovation or teacher learning - a concern noted by most of the authors in this volume. Given that comprehensive support is not likely to be feasible in most settings, those who aspire to create and maintain a supportive infrastructure for CCD must anticipate the need to weigh trade-offs regarding where to target their efforts. The synthesis provided in Table 22.1 (along with the details above and throughout the chapters of this book) provides empirically-grounded starting points for making such decisions.

\section{Recommendations for Further Research}

The findings given in Table 22.1 constitute recommendations for policymakers and practitioners who would undertake CCD. Here, in light of those findings, recommendations for further research are given. First, in terms of CCD processes, it seems notable that only a few studies touched explicitly on the supports needed by colleagues not participating in the CCD team. Research on this topic seems especially 
relevant for achieving the goal of sustainability. Second, to assess the overall value of CCD for curriculum innovation, it seems prudent to investigate the quality of the materials designed. This was hardly undertaken in these studies, yet tools for doing so are available, such as the Educators Evaluating the Quality of Instructional Products (EQuIP) rubrics (https://www.achieve.org/our-initiatives/equip/aboutequip). While some research into the human aspects of infrastructure provides insight into how to prepare leadership and facilitators, additional work in this area is needed, as many challenges remain. While materials to support curriculum innovation and teacher learning in general are present, further research is needed to design, test, and refine resources specifically for CCD teams. In so doing, they should take into account the differing needs of teams prioritizing curriculum innovation, in contrast to those prioritizing teacher learning. On the whole, the structural aspects of infrastructure to support CCD seem particularly challenging, because issues of time together and planning for iterative experimentation have been predictable based on the existing literature. Research is therefore needed to understand the causes of these persistent problems and to identify ways to infrastructure solutions together. Finally, we need studies that reveal how to organize the processes of infrastructuring, as these have rarely been the explicit focus of empirical inquiry.

\section{Closing Remarks}

The purpose of this chapter was to explore whether and how the infrastructure needed for CCD targeting curriculum innovation aligns with that required by CCD for teacher learning, and vice versa. This exploration was undertaken by distilling key insights from the cases described throughout this book, using the human, material, and structural aspects of infrastructure as a lens. The evidence synthesized from the chapters in this volume pointed toward nine key elements of the infrastructure to support both curriculum innovation and teacher learning through CCD. For both goals, crucial human aspects of infrastructure were leadership, expert facilitation, and expertise in the team; crucial material aspects of infrastructure were exemplary materials, tools, and literature; and crucial structural aspects of infrastructure were organizing time together, promoting use of data, and facilitating iterative experimentation. Simultaneously, this chapter also identified important elements of the human, material, and structural aspects of CCD infrastructure that are specific to each distinct primary goal, namely, curriculum innovation or teacher learning (shown as plain text in Table 22.1).

As described by the editors in the first chapter of this volume, this book was designed to provide international perspectives on the active involvement of teachers in CCD for sustainable curriculum innovation and teacher learning across diverse contexts. The chapters throughout this book illustrate various forms of synergies between curriculum development and teacher learning, as well as the social, cultural, and activity-based nature of CCD work. Penuel (this volume) argued for the importance of leveraging CCD not only to reach goals of curriculum change and 
teacher learning, but also to build collective capacity for equitable change. Toward that end, this chapter offers empirically-derived priorities for infrastructuring the contexts in which CCD is undertaken.

\section{References}

Avalos, B. (2011). Teacher professional development in teaching and teacher education over ten years. Teaching and Teacher Education, 27(1), 10-20.

Ball, D., \& Cohen, D. (1996). Reform by the book: What is - Or might be - The role of curriculum materials in teacher learning and instructional reform? Educational Researcher, 25(9), 6-8, 14.

Ball, D. L., \& Cohen, D. K. (1999). Developing practice, developing practitioners: Toward a practice-based theory of professional education. In L. Darling-Hammond \& G. Sykes (Eds.), Teaching as the learning profession: Handbook of policy and practice (pp. 2-22). San Francisco: Jossey Bass.

Becuwe, H., Tondeur, J., Pareja Roblin, N., Thys, J., \& Castelein, E. (2016). Teacher design teams as a strategy for professional development: The role of the facilitator. Educational Research and Evaluation, 22(3-4), 141-154.

Ben-Peretz, M. (1990). The teacher-curriculum encounter. Albany, NY: State University of New York Press.

Binci, D., Cerruti, C., \& Braganza, A. (2016). Do vertical and shared leadership need each other in change management? The Leadership \& Organization Development Journal, 37(5), 558-578. https://doi.org/10.1108/LODJ-08-2014-0166

Binkhorst, F., Poortman, C. L., McKenney, S., \& van Joolingen, W. R. (2018). Revealing the balancing act of vertical and shared leadership in teacher design teams. Teaching and Teacher Education, 72, 1-12.

Binkhorst, F., Poortman, C. L., \& Van Joolingen, W. R. (2017). A qualitative analysis of teacher design teams: In-depth insights into their process and links with their outcomes. Studies in Educational Evaluation, 55, 135-144.

Borko, H. (2004). Professional development and teacher learning: Mapping the terrain. Educational Researcher, 33, 3-15.

Boschman, F., McKenney, S., Pieters, J., \& Voogt, J. (2016). Exploring the role of content knowledge in teacher design conversations. Journal of Computer Assisted Learning, 32(2), 157-169. https://doi.org/10.1111/jcal.12124

Boschman, F., McKenney, S., \& Voogt, J. (2014). Understanding decision making in teachers' curriculum design approaches. Educational Technology Research and Development, 62, 393-416.

Boschman, F., McKenney, S., \& Voogt, J. (2015). Exploring teachers' use of TPACK in design talk: The collaborative design of technology-rich early literacy activities. Computers \& Education, $82,250-262$.

Brown, J. S., \& Duguid, P. (1991). Organizational learning and communities-of-practice: Toward a unified view of working, learning, and innovation. Organization Science, 2(1), 40-57.

Clarke, D., \& Hollingsworth, H. (2002). Elaborating a model of teacher professional growth. Teaching and Teacher Education, 18(8), 947-967.

Cobb, P. (1994). Where is the mind? Constructivist and sociocultural perspectives on mathematical development. Educational Researcher, 23(7), 13-20.

Coburn, C., \& Russell, J. (2008a). District policy and teachers' social networks. Educational Evaluation and Policy Analysis, 30(3), 203-235.

Coburn, C., \& Russell, J. (2008b). Getting the most out of professional learning communities and coaching: Promoting interactions that support instructional improvement. Learning Policy Brief, 1(3), 1-5. 
Coburn, C. E., Penuel, W. R., \& Geil, K. E. (2013). Research-practice partnerships: A strategy for leveraging research for educational improvement in school districts. Retrieved from http:// files.eric.ed.gov/fulltext/ED568396.pdf

Cochran-Smith, M., \& Lytle, S. L. (2001). Beyond certainty: Taking an inquiry stance on practice. In A. Lieberman \& L. Miller (Eds.), Teachers caught in the action: Professional development that matters (pp. 45-58). New York: Teachers College Press.

Cviko, A., McKenney, S., \& Voogt, J. (2014). Teacher roles in designing technology-rich learning activities for early literacy: A cross-case analysis. Computers \& Education, 72, 68-79.

Dantec, C. A. L., \& DiSalvo, C. (2013). Infrastructuring and the formation of publics in participatory design. Social Studies of Science, 43(2), 241-264.

Darling-Hammond, L., \& McLaughlin, M. W. (1995). Policies that support professional development in an era of reform. Phi Delta Kappan, 76(8), 597-604.

Davis, E., \& Krajcik, J. (2005). Designing educative curriculum materials to promote teacher learning. Educational Researcher, 34(3), 3-14.

Diamond, J. B., \& Spillane, J. P. (2004). High-stakes accountability in urban elementary schools: Challenging or reproducing inequality? Teachers College Record, 106(6), 1145-1176.

Dolle, J. R., Gomez, L. M., Russell, J. L., \& Bryk, A. S. (2013). More than a network: Building professional communities for educational improvement. National Society for the Study of Education Yearbook, 112, 443-463.

Drake, C., Land, T., \& Tyminski, A. (2014). Using educative curriculum materials to support the development of prospective teachers' knowledge. Educational Researcher, 43(3), 154-162.

Garet, M. S., Porter, A. C., Desimone, L., Birman, B. F., \& Yoon, K. S. (2001). What makes professional development effective? Results from a national sample of teachers. American Educational Research Journal, 38(4), 915-945.

Gerard, L. F., Bowyer, J. B., \& Linn, M. C. (2010). How does a community of principals develop leadership for technology-enhanced science. Journal of School Leadership, 20(2), 145-183.

Grossman, P., \& Thompson, C. (2008). Learning from curriculum materials: Scaffolds for new teachers? Teaching and Teacher Education, 24, 2014-2026.

Hargreaves, A. (2003). Teaching in the knowledge society: Education in the age of insecurity. New York: Teachers College Press.

Hopkins, M., \& Spillane, J. P. (2015). Conceptualizing relations between instructional guidance infrastructure (IGI) and teachers' beliefs about mathematics instruction: Regulative, normative, and cultural-cognitive considerations. Journal of Educational Change, 16(4), 421-450.

Hopkins, M., Spillane, J. P., Jakopovic, P., \& Heaton, R. M. (2013). Infrastructure redesign and instructional reform in mathematics. Elementary School Journal, 114(2), 200-224.

Hord, S. M. (2009). Professional learning communities. Journal of Staff Development, 30(1), $40-43$.

Horn, I. S., Garner, B., Kane, B. D., \& Brasel, J. (2016). A taxonomy of instructional learning opportunities in teachers' workgroup conversations. Journal of Teacher Education, 68, 41-54. https://doi.org/10.1177/0022487116676315

Horn, I. S., \& Kane, B. D. (2015). Opportunities for professional learning in mathematics teacher workgroup conversations: Relationships to instructional expertise. Journal of the Learning Sciences, 24(3), 373-418.

Kali, Y., McKenney, S., \& Sagy, O. (2015). Teachers as designers of technology enhanced learning. Instructional Science, 43(2), 173-179.

Kali, Y., \& Ronen-Fuhrmann, T. (2011). Teaching to design educational technologies. The International Journal of Learning and Technology, 6(1), 4-23.

Koehler, M., \& Mishra, P. (2005). What happens when teachers design educational technology? The development of technological pedagogical content knowledge. Journal of Educational Computing Research, 32(2), 131-152.

Lave, J., \& Wenger, E. (1991). Situated learning: Legitimate peripheral participation. Cambridge, UK: Cambridge University Press. 
Lee, O., Penfield, R., \& Maerten-Rivera, J. (2009). Effects of fidelity of implementation on science achievement gains among English language learners. Journal of Research in Science Teaching, 46(7), 836-859.

Lewis, C., Perry, R., \& Murata, A. (2006). How should research contribute to instructional improvement? The case of lesson study. Educational Researcher, 35(3), 3-14.

Linn, M. C., Gerard, L., Matuk, C., \& McElhaney, K. W. (2016). Science education: From separation to integration. Review of Research in Education, 40(1), 529-587.

Little, J. W. (1999). Organizing schools for teacher learning. In L. Darling-Hammond \& G. Sykes (Eds.), Teaching as the learning profession: Handbook of policy and practice (pp. 233-262). San Francisco: Jossey-Bass.

McKenney, S. (2008). Shaping computer-based support for curriculum developers. Computers \& Education, 50(1), 248-261.

McKenney, S. (2013). Designing and researching technology enhanced learning for the zone of proximal implementation. Research in Learning Technology, 21, 17374.

McKenney, S. (2017). Een infrastructuur voor de professionele groei van docenten [Infrastructuring teacher professional growth; inaugural lecture]. Enschede, The Netherlands: University of Twente.

McKenney, S., Kali, Y., Markauskaite, L., \& Voogt, J. (2015). Teacher design knowledge for technology enhanced learning: An ecological framework for investigating assets and needs. Instructional Science, 43(2), 181-202.

Neal, J. W., Mills, K. J., McAlindon, K., Neal, Z. P., \& Lawlor, J. A. (2018). Multiple audiences for encouraging research use: Uncovering a typology of educators. Educational Administration Quarterly. https://doi.org/10.1177/0013161x18785867

Pareja Roblin, N., Schunn, C., Bernstein, D., \& McKenney, S. (2018). Exploring shifts in the characteristics of US government-funded science curriculum materials and their (unintended) consequences. Studies in Science Education, 54(1), 1-39.

Pareja Roblin, N., Schunn, C., \& McKenney, S. (2018). What are critical features of science curriculum materials that impact student and teacher outcomes? Science Education, 102(2), 260-282.

Penuel, W. R. (2015). Infrastructuring as a practice for promoting transformation and equity in design-based implementation research. Paper presented at the meeting of the International Society for Design and Development in Education, Boulder, Colorado.

Penuel, W.R. (2019). Infrastructuring as a practice of design-based research for supporting and studying equitable implementation and sustainability of innovations. Journal of the Learning Sciences. https://doi.org/10.1080/10508406.2018.1552151

Penuel, W. R., Fishman, B. J., Yamaguchi, R., \& Gallagher, L. P. (2007). What makes professional development effective? Strategies that foster curriculum implementation. American Educational Research Journal, 44(4), 921-958.

Putnam, R., \& Borko, H. (2000). What do new views of knowledge and thinking have to say about research on teacher learning? Educational Researcher, 29(1), 4-15.

Remillard, J. (2000). Can curriclum materials support teachers' learning? Two fourth-grade teachers' use of a new mathematics text. The Elementary School Journal, 100(4), 331-350.

Remillard, J. T., Herbel-Eisenmann, B. A., \& Lloyd, G. M. (Eds.). (2011). Mathematics teachers at work: Connecting curriculum materials and classroom instruction. New York: Routledge.

Resnick, L., Levine, J., \& Teasley, S. (Eds.). (1991). Perspectives on socially shared cognition. Washington, DC: American Psychological Association.

Schildkamp, K., Lai, M. K., \& Earl, L. (Eds.). (2012). Data-based decision making in education: Challenges and opportunities (Vol. 17). Dordrecht, The Netherlands: Springer.

Star, S. L., \& Ruhleder, K. (1996). Steps toward an ecology of infrastructure: Design and access for large information spaces. Information Systems Research, 7(1), 111-134.

Stenhouse, L. (Ed.). (1980). Curriculum research and development in action. London: Heinemann.

Tytler, R., Symington, D., \& Smith, C. (2011). A curriculum innovation framework for science, technology and mathematics education. Research in Science Education, 41(1), 19-38. 
Van den Akker, J. (1998). The science curriculum: Between ideals and outcomes. In B. Fraser \& K. Tobin (Eds.), International handbook of science education (pp. 421-447). Dordrecht, The Netherlands: Kluwer Academic Publishers.

Van Veen, K., Zwart, R., Meirink, J., \& Verloop, N. (2010). Professionele ontwikkeling van leraren: Een reviewstudie naar effectieve kenmerken van professionaliseringsinterventies van leraren. [Professional development of teachers: A review study on effective characteristics of professionalization interventions]. Leiden, The Netherlands: ICLON/Expertisecentrum Leren van Docenten.

Windschitl, M., Thompson, J., Braaten, M., \& Stroupe, D. (2012). Proposing a core set of instructional practices and tools for teachers of science. Science Education, 96(5), 878-903.

Open Access This chapter is licensed under the terms of the Creative Commons Attribution 4.0 International License (http://creativecommons.org/licenses/by/4.0/), which permits use, sharing, adaptation, distribution and reproduction in any medium or format, as long as you give appropriate credit to the original author(s) and the source, provide a link to the Creative Commons licence and indicate if changes were made.

The images or other third party material in this chapter are included in the chapter's Creative Commons licence, unless indicated otherwise in a credit line to the material. If material is not included in the chapter's Creative Commons licence and your intended use is not permitted by statutory regulation or exceeds the permitted use, you will need to obtain permission directly from the copyright holder.

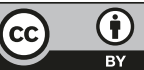

